\title{
GUILT AND CULPABILITY IN THE LAW OF GREAT MORAVIA ${ }^{1}$
}

\author{
Róbert Jáger
}

DOI: 10.17846/CL.2021.14.2.26-36

\begin{abstract}
JÁGER, Róbert. Guilt and Culpability in the Law of Great Moravia. The article describes the forms of guilt and culpability in the so-called normative texts of Great Moravia (Nomocanon, Admonitions to the Rulers and the Judicial Code for the People). The first part of the article describes the parts of the Judicial Code for the People, in which the actions are described, which we could define by modern legal understanding as intentional culpability and negligent culpability. In these provisions there are also indications of a distinction between direct and indirect intentions, and conscious and unconscious negligence. The author of the article considers in the text whether such a distinction of forms of culpability could have existed before the arrival of the Byzantine mission, or whether the distinction is the benefit of Byzantine (Roman) law for the domestic law of Great Moravia. The author also considers how these provisions have been implemented in practice. He points out that the rules in question contained a double sanction: secular and ecclesiastical sanctions, and sought to determine which of those sanctions had been imposed in practical life.
\end{abstract}

Keywords: Great Moravia, guilt, culpability, Old Church Slavonic, law

The concepts of guilt and culpability belong to the main concepts of contemporary law, whether in its legal-theoretical or positive-legal level. We encounter the term guilt in the Slovak language and in written documents written in Slovak from the earliest times of its development. However, the meaning of this word has differed slightly over the course of more than a thousand years of Slovak development, and in different periods it had its own specific meaning. The fact that the word guilt has been used since the earliest developmental periods of Slovak, as well as the use of words very similar or identical to Slovak guilt in other Slavic languages, indicates the use of this word in the period preceding origin of the Slovak language, which is generally placed at the turn of the 10th and the 11th century (Stanislav, 1956). Evidence of the use of the word guilt in the period preceding origin of the Slovak language, i. e., in the period of the use of Slavonic and Old Church Slavonic, is its abundant occurrence in the sources of the Great Moravian period.

As far as the scope of the use of the word guilt and its derivatives is concerned, the richest Great Moravian normative text is Nomocanon. This contains up to 41 uses of the word guilt or its derivatives. The Old Church Slavonic word vina (guilt) (in various grammatical variations - vina, vinoju, viny, vinu) was used a total of 16 times in the text. ${ }^{2}$ The Old Church Slavonic word povinen (in various grammatical variations - povinovati sę, povinets se, povinonb, povinutie et c.) was used a total of 25 times in the text. ${ }^{3}$

1 The article is the output of the grant project APVV-16-0362 Privatization of Criminal Law - Substantive, Procedural, Criminological and Organizational - Technical Aspects.

2 The Old Church Slavonic word vina (guilt) and its various grammatical forms were mentioned in the text of the Nomocanon on the following pages (we present page numbers according to Bartoňková, Dagmar et al. (1971) in the further citation of this work we use the abbreviation MMFH IV/:249, 254, 256, 268, 276, $278,288,371,312,312,315,341,341,342,353,358$.)

3 The Old Church Slavonic word povinen (obliged) and its various grammatical forms were mentioned in 
The Nomocanon contains the following uses of the Old Church Slavonic word vina with the meaning given in parentheses: ${ }^{4}$ ne svojeju ich vinoju (not by their fault ${ }_{249}$ ), vinoju (under the pretext ${ }_{254}$ ), vinoju (under the guise / under the pretext ${ }_{256}$ ), vinoju (under the guise / under the pretext $_{268}$ ), $i$ inoja radi viny (for another reason ${ }_{276}$ ), vina $\left(\right.$ reason $_{278}$ ), vinoju (under the pretext ${ }_{311}$ ), vinoju (under the pretext ${ }_{312}$ ), smotriti viny (investigate the causes ${ }_{312}$ ), vinoju (under the pretext ${ }_{315}$ ), bez viny jests (is without guilt ${ }_{341}$ ), bez viny sutb (are without guilt ${ }_{341}$ ), viny (guilty ${ }_{353}$ ), sam sebe vinona tvoritb (he blames himself ${ }_{358}$ ).

Based on this calculation, we can state that the Old Church Slavonic word guilt was used in Nomocanon 9 times with the meaning of reason, cause or pretext, and only 4 times the meaning of this word was in the form of Slovak vina (guilt) and vinný (guilty). It can therefore be stated that the Nomocanon used Old Church Slavonic vina (guilt) mainly to indicate cause or reason, and only to a lesser extent to indicate guilt. Given that Nomocanon is more or less a translation of a Greek model ${ }^{6}$ that does not reflect the legal situation in Great Moravia, and given that other normative texts of the Great Moravian period also reflect the issue of guilt and culpability, we present in the following part the provisions of those parts of texts of Great Moravian origin, which directly or indirectly deal with the issue of guilt and culpability.

Despite the fact that the word vina (guilt) also existed in the Old Church Slavonic language, its use in the normative texts of the Great Moravian period is not common. Less rare is only the use of derivatives of the word guilt in the form of obligation, obligatory etc. However, despite the rare use of the Old Church Slavonic word vina (guilt) and the less rare use of derivatives of the word vina (guilt) in normative texts of the Great Moravian period, the issue of guilt, culpability, even some indication of differentiating various "forms of guilt" or indications of "acquittal" is relatively detailed in several places. ${ }^{7}$

Unlike Admonitions to the Rulers, which do not contain the direct use of the word guilt, but contain only the use of its derivatives, the Judicial Code for the People ("JCP") also contains one direct use of the word guilt in article $16 .{ }^{8}$ In addition, it also contains the repeated use of the word obligation, obligatory in its 4 th article, ${ }^{9}$ in article no. $7 \mathrm{a},{ }^{10}$ in article no. $8,{ }^{11}$ and in article no. $30 .{ }^{12}$

the text of the Nomocanon on the following pages MMFH IV: 253, 256, 261, 266, 270, 271, 273, 295, 302, $306,312,313,313,314,318,319,320,330,339,339,341,346,348,353,363$.

4 Number given in the form of ${ }_{\text {a lower index }}$ refers to a page in the Nomocanon in MMFH IV in its first edition when the word vina (guilt) is mentioned.

5 Jako ne dostoitb s(vę)št(e)niku svojeja žend izgoniti vinoju gověnija ni po s(vę)št(e)nii ženiti sę, razvě tzkmo $n e s(v e ̨)$ št $(e)$ nomu podobajets ženiti sę. A priest may not expel his wife either under the pretext of piety or marry after consecration, only the uninitiated can marry.

6 On the influence of Byzantine law and Byzantine culture on the development of material aspects of society in Great Moravia, see the work of Peter Ivanič (2016, 3-10).

7 We put the above phrases in quotation marks due to the fact that there were no equivalents for these terms in the contemporary language.

8 Let him who flees here acquaint the priest with his affair and the guilt he has committed.

9 They are obliged to eat nothing but bread and water for seven years.

10 About witnesses. Regarding all these (perpetrators), the prince and the judge should conduct an investigation with all care and patience, and not condemn without witnesses. However, one must seek true witnesses, fearful of God, respected, and those who have no hatred, no malice, no anger, no dispute, no accusation against those they testify of, but only fear of God and his righteousness. Let the number of witnesses be eleven or more than this number.

${ }_{11}$ However, if he is poor, have the judge flog him and expel him from his district. He is also obliged to submit to repentance for seven years, as we have written.

12 Whoever lures someone else's slave to himself, hides him and does not say where he is, is obliged to return him to his master or give him another, or his price. 
For getting to know the Slavonic and Old Church Slavonic terms used to denote the word guilt is interesting art. 16 of JCP, as this contains a direct use of the word guilt. It states as follows: Nikyi že priběgajoštajego vo crok̋vo noždajo, no věšts priběgyi javljajetr popovi vino otr nego sotvorenojo, da priimletz jego ubega. Jako da po zakonu izištetr sę i ispytajetz sę obida jego. Ašte li kəto pokusitъ sę noždami otø crbkbve izvesti priběgbšajego, køto ljubo bodi, da priimetr $\mathrm{rm}^{13}$ rani, i təgda jako podobajetz da ispytajetz se obida priběgzšujemu. Let no man put away him that fleeth into the temple by force: but let the refugee reveal the thing, and the guilt which he hath done, unto the priest, and let him accept him. As under the law let his guilt be examined and investigated. If someone tries to force a refugee out of the church by force, whoever it is, may they accept 140 blows, and then may the guilt of the refugee be investigated as appropriate (Žigo Kučera 2012, 110).

Even at the first glance at the Slovak translation, it can be noticed that there is up to three times the term guilt mentioned in the provision of the JCP in question. However, by comparison with the original Old Church Slavonic text, we find a slight discrepancy. While in the Slovak translation the word vina (guilt) is found three times, in the Old Church Slavonic draft the word vino (guilt) is found only once, and the other two Slovak words vina (guilt) have the Old Church Slavonic equivalent obida. It might seem that Old Church Slavonic thus knew two terms used to denote contemporary Slovak vina (guilt), i. e. vino and obida. This is not the case: in the Etymological Dictionary of Old Church Slavonic ${ }^{14}$, we find both of the following meanings in the entry obida: wrong, injustice, evil, crime, dispute, unfairness (Erhart, 1999, 562). The meaning of "guilt" is not among those listed. Similarly, Dayachenko does not even mention the meaning of "guilt" in his dictionary $(1993,362)$. The given translation may therefore be considered not the most appropriate, and it would be more appropriate for the two uses of the Old Church Slavonic word obida to be translated as "dispute" or "injustice" or "wrong". The translation contained in the MMFH IV is also in such a form. ${ }^{15}$

However, the Judicial Code for the People contains an article which, although it does not directly contain the term guilt or its derivatives, nevertheless most comprehensively regulates the perception of culpability in contemporary law. This is art. 15 regulating arson: setting fire to houses of other people with the differentiating between the setting fire to houses in towns and in the country. (Due to the larger extent of this provision, we have divided it into individual paragraphs and numbered them. There is no such division and numbering of the text in the original text).

1. Iže za jetery vraždy li grablenøja děla iměnija ognımь vъžagajetz chramy, ašte vo gradě, da ognьmь szžagajotъ $i$, ašte li $v_{\mathrm{b}} v_{\mathrm{b}}$ si ili $v_{\mathrm{b}}$ selě mečemь da usěkajotъ $i$. A po crъkъ $v_{\mathrm{b}} n u j e m u$ zakonu vъ postz $\mathrm{vi}^{16}$ létz prědajetz sę, jako vražıbınikz jestz. Whoever sets fire to residential buildings because of enmity or the robbery of property, let him burn if it is in the town. If it is in the village or in the estate, let him be executed with the sword. But under ecclesiastical law, he is surrendered for repentance for 12 years, because he is the enemy.

13140.

14 Kurz, 1972.

15 Let no one forcibly bring out of the temple who flees into the temple, but let him who has fled here explain his case and the guilt he has committed to the priest, and let him take him as a refugee, so that his crime may be examined and investigated according to the law. If anyone, whoever it is, tries to force a man out of the temple who has escaped here by force to receive 140 blows, and then, as is appropriate, the crime of the one who has escaped be investigated. MMFH IV, 188.

1612. 
2. Ašte li kzto stbbloje ili tronbje chote požešti na svojei nivě vazgnětitъ ognb, tože ognb prošbdo vbzbžetr štuždo nivo ili (štuždb) vinogrado, dostoitr soditi $i$ ispytati, da ašte vo nevěděnbje ili va modlostvo vazgnětivøšju ogns sę bodetr. If someone, a stubble or thorns wanting to burn on their floodplain sets a fire, that fire spreads and sets a fire to another person's floodplain or a vineyard, it is necessary to judge and examine whether due to the inexperience or dullness of the person who set the fire this happened.

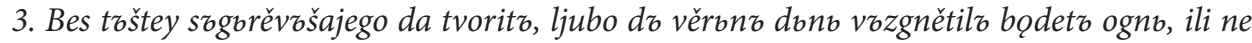

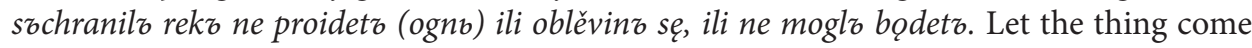
to pass without harm to the one who suffered the loss due to the fire, if he kindles a fire on a windy day, or has not safeguarded it, thinking that the fire will not spread, or will not do so out of laziness, or that he cannot.

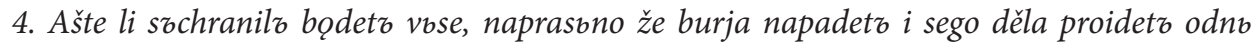
daleče, da ne osoditz sę. If he has provided everything, but suddenly the storm falls, and therefore the fire spreads further, let him not be condemned.

5. Ašte otz toče zažagajetz se chrams ili i požbžetz jetero čbto otz svojego jemu chrama

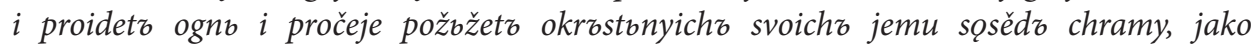
vъnezaprvo byvъšu роžьženъju tomu ne osoždajetъ sę. If a house be kindled by lightning, and something from his house shall be burned, and fire shall break and continues to set fire to his neighbours' houses because suddenly a fire broke out, he is not condemned (Žigo Kučera 2012, 110).

The first paragraph of article 15 of the JCP regulates an action in which someone sets fire to a residential building due to robbery, and imposes a sanction in the form of execution by burning (if the act happened in the town) or by cutting with a sword (if the act happened in the country), or by fasting according to ecclesiastical law. ${ }^{17}$ The arson of a residential building due to robbery can be classified in the modern sense of the law as "intentional culpability"18 with "direct intent". In the case of committing an act in the town, it can be stated that the sanction in the form of burning is a looser application of the Old Testament "eye for eye, tooth for tooth"19: the perpetrator will be burned for setting the house on fire. ${ }^{20}$ Even when setting a building on fire in the town and in the countryside, the execution of the perpetrator is a sanction, but when committing an act in the town, the execution should be carried out in a more painful and slower way. We could only assume why there was such a distinction between arson and in the town and countryside: it may be due to the higher risk of fire spreading to other buildings in the town, which in the Middle Ages often caused "burning to ashes" of entire urban areas, while rural buildings were more distant from each other at the time and were not arranged "along the way" as it is today (this

17 On the issue of the administration of church affairs in our territory, see the work of Viliam Judák (1997) in more detail.

18 We use quotation marks to refer to the phrases "intentional culpability" and "negligent culpability" as these are terms unknown to contemporary law and their use in this text is a neologism.

19 onsistent application of the "eye for eye, tooth for tooth" rule should be a sanction for the perpetrator to set fire to his house. The analogy, however, can be seen in the fact that if the "legislator" chose the death penalty for the perpetrator of arson, he chose the same means of death as the act was committed, that is, by fire. We put the word of the legislator in quotation marks because the author of the JCP is Methodius, who did not have the status of a body authorized by the legislature in Great Moravia.

20 The principle of similarity between the punishment and the sanction following the action can also be found in Article 29 of the JCP. It stipulates: Whoever steals a free man and sells or enslaves him, let him be enslaved himself, since he also enslaved the free man, let him enter into the same servitude. In this provision, the penalty of enslavement for enslavement is directly justified in the text of the JCP standard. 
type of rural urbanization in our territory begins to take place only in connection with German colonization $)^{21}$ and thus the risk of spreading fire from one building to another in the countryside was lower. If the said distinction between different methods of execution was indeed justified by the different degree of risk of the fire spreading to other buildings, we can assume that the first paragraph of art. 15 of the JCP implicitly foreshadowed the regulation of the action, which we would call in today's language "intentional conduct with indirect intent", i. e., the conduct in which the perpetrator set fire to the house due to robbery ("direct intent") but this could have spread in the town due to closer location of buildings to other buildings ("indirect intention"). ${ }^{22}$ The last sentence of the first paragraph is also worth mentioning. ${ }^{23}$ It sanctions an act in which someone set fire to a residential building for robbery, not with a death penalty, but with a church penance. This is a phenomenon that occurs multiple times in the JCP, and the essence of which was probably to alleviate too harsh sanctions of secular law. ${ }^{24}$ However, it is not clear from the wording of the first paragraph which sanction was actually implemented in practical life. If the perpetrator was executed under secular law, it was not possible to impose repentance under ecclesiastical law. If the perpetrator was repented, secular law would remain unexecuted. We can only assume how this provision of the JCP was really implemented in practice, and whether sanctions of secular or ecclesiastical law were used to punish the perpetrator.

The implied discrepancy between the severity of the sanction imposed under secular law and the mildness of the sanction imposed under ecclesiastical law gives much scope for assessing all the circumstances of the particular case in which the act was committed, which we would call "mitigating" or "aggravating" circumstances in modern law. The retention of a sanction under secular law in most provisions of the JCP can be justified by a rather preventive-deterrent function: the potential perpetrator was to be deterred by a strict sanction of secular law, but could ultimately be repented. However, the above considerations on the preference of ecclesiastical fasting over the stricter death penalty are only the opinion of the author, which can be largely influenced by the current understanding of the law.

If we want to approach the contemporary interpretation of the indicated contradiction, we have not any preserved document from the Great Moravian area that could serve us for this task. However, a letter has been preserved in which Pope Nicholas I answered the questions of the Bulgarians from 866, i. e., from the time near the creation of the most important normative texts of the Great Moravian period. At the same time, the Bulgarian society was at a similar stage of

21 As to the topic in question see the work of Dušan Kováč et al. $(1998,137)$ in more detail.

22 But in order for this to be an indirect intention in the sense of today's understanding, the perpetrator would have to understand that the fire could spread. In this case, it is important that the perpetrator wanted to act (e. g. set fire to house A in the city) even at the cost that the fire could spread to house B in the city. Either the fire would spread or not spread, so there would be a criminal as well as a non-criminal alternative, and the perpetrator knew and could have anticipated both of these alternatives and still wanted to act - set house A on fire. Therefore we may marginally state that there was also an indication of indirect intent, taking into account the fact that the fire in the city could actually spread due to the proximity of houses. Author of the note: Doc. JUDr. Simona Ferenčíková, PhD

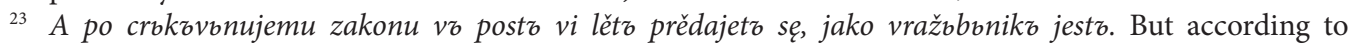
ecclesiastical law, he is surrendered for repentance for 12 years, because he is the enemy.

24 In the JCP, capital and crippling punishments are even more alleviated and replaced by ecclesiastical penance (fasting), according to Western European patterns distinguishing different degrees of penance. This may have reflected the attitude of the domestic population towards inappropriate cruel forms of punishment. Moreover, in the imposition of sentences, no distinction is made at all between the social status of perpetrators and victims (their affiliation to different social classes), which could also suit the social establishment of Great Moravia (Saturník 1922, 11). 
development as the Great Moravian one ${ }^{25}$, and in questions addressed to the Pope they deal with similar problems as in Great Moravia. The Bulgarians, too, have gradually embraced Christianity, and have had many questions ${ }^{26}$ to answer. In the above letter, the Pope patiently answers their questions in detail and sensitively, sometimes with a high philosophical and theological commitment. $^{27}$

The contradiction outlined above is not directly resolved between the Bulgarian questions and the Pope's answers, but the following can be abstracted from the spirit of the whole text: the Pope acknowledges the existence of both secular and spiritual laws, and recommends observing only "venerable secular laws." He also repeatedly recommends the commutation of sentences ${ }^{28}$ and explicitly recommends permission to repent if the criminal wants to do so, and no one should prevent him from doing so. ${ }^{29}$ Although we do not have a similar "implementing regulation" to normative texts from the times of Great Moravia, Methodius could have fulfilled the role of "interpreter" of these texts. And Methodius, as a person familiar with ecclesiastical law as well as of Christian philosophy, Christian doctrine or worldview, would probably take a similar view to the one presented in the letter of Pope to the Bulgarians, analogical to the above-mentioned contradiction.

Pope's letter to the Bulgarians can also indirectly give us an answer to the question outlined above, whether submitting to ecclesiastical repentance can replace punishment under secular law. Pope's answer XLI states that "every sin is completely washed away by repentance" ${ }^{30}$ Even more apt is the last sentence of the answer, XXVL: "I do not want the death of a sinner, but that he should be converted and alive" ${ }^{31}$ If this answer of the Pope reflects the general understanding of the fact at that time, and we assume that, at least for the clergy, yes, we dare to support the above statement that Methodius would incline to a milder "sanction" under ecclesiastical law in a particular case.

${ }_{25}$ However, the development in Great Moravia was in some respects at a slightly higher level of development, ahead of the development in Bulgaria by several decades. Nevertheless, the contemporary interpretation and understanding of the norms of the law of a given society contained in the Pope's letter is applicable not only to Great Moravia but also to other countries with developing Christianity.

26 The letter of the Pope to the Bulgarians consists of 106 (more or less) extensive answers, and each answer begins with a kind of "introduction to the issue", from which it is relatively easy to abstract the original question of the Bulgarians.

27 It is probable that the author of this document was not directly Nicholas I, but his secretary Anastasius Bibliothecarius, administrator of the papal archive and head of the office (Vavř́nek, 2013). Anastasius also met Constantine and Methodius personally during their stay in Rome. Peter Ivanič and Martina Lukáčová (2014b, 9-11) addressed the issue of the journey of Constantine and Methodius to Rome. In his work, Martin Husár also addressed the questions of the ceremonial course of the meetings of Constantine and Methodius in Rome $(2016,2938)$.

28 Circa hos, qui quando ad pugnam contra hostes proceditis, fugam arripiunt, si non misericorditer praeveniat compassio, saltem legum temperetur severitas. As for those who flee [...] at least the strictness of the laws let be eased if merciful compassion is not applied (MMFH IV, 49).

$29 \mathrm{Si}$, quemadmodum assertis, sponte poenitentiam agere volunt, non sunt prohibendi, sed per omnia poenitentiae summittendi, quam episcopus vel presbyter ordinatus ab illo considera verit. Nam non suscipere poenitentes non est catholicorum, sed Novatanorum. If they want, as you assure, to perform voluntary repentance, they should not be prevented from doing so, but submit to all the repentance that the bishop or priest ordained by him deems good, because not accepting penitents is not a feature of Catholics but novices (MMFH IV, 77).

30 Utique denique omne peccatum paenitentia, quae nonnisi Dei gratia comitante proficit, omnino diluitur (MMFH IV, 43).

31 "Nolo," inquit Dominus, "mortem peccatoris, sed ut convertatur et vivat" (MMFH IV, 51). 
The second paragraph of article 15 of the JCP generally deals with the need to examine the situation if someone lights a fire on their own property, and this will be spread further. This is a situation where someone lights a fire without the intention of damaging other people's property. It is therefore a conduct which does not and cannot take the form of "intentional culpability", as was the case in the situations covered by the first paragraph. The conduct described in the second paragraph therefore takes the form of "unintentional/negligent culpability". The following third and fourth paragraphs describe the situations from which we can abstract different forms of "negligent culpability".

The third paragraph describes the case where someone set a fire on a windy day, as well as the reasons why he did not take measures against the spread of fire: a) did not take measures against the spread of fire because he thought that the fire would not spread, b) did not take measures against the spread of fire for his ignorance c) did not take measures against the spread of fire because of his laziness. The first sentence of this paragraph begins with the words "without harm to the one who suffered the loss due to the fire". This wording can be interpreted as meaning that the person who started the fire (without intending to damage other people's property) is to compensate the injured party as a result of inaction - failure to take the necessary measures due to reliance on the fire not spreading or for failure to take the necessary measures due to their ignorance or laziness. It is a form of "negligent culpability".

Important for distinguishing between situations that we would describe in modern law as the "intentional culpability" contained in the first paragraph and the "negligent culpability" contained in the following paragraphs is the serious difference in the consequences of such conduct. In conduct having the characteristics of "intentional culpability", art. 15 of the JCP provided for the death penalty (with possible reparation by ecclesiastical penance), in conduct having signs of "negligent culpability" the result was compensation for the damage caused.

However, the fourth paragraph regulates the situation where the person who lit the fire did everything to prevent it from spreading, but only because of a natural event, the fire spread and damaged other people's property. He who started a fire and it spread only due to a natural event and damaged other people's property should not be condemned. By free interpretation and comparison with the wording of the third paragraph we can state that while in the third paragraph there is an obligation to pay damages, the fourth paragraph does not claim such damages, as the one who lit the fire did everything to prevent it from spreading and its spread was caused just by a natural event. The fourth paragraph therefore governs "negligent culpability", the degree of culpability of which is lower than that of the "negligent culpability" contained in the third paragraph, and no compensation is sought due to that lower degree of "negligent culpability". The degree of "negligent culpability" in this case is reduced to practically a minimum. This reduction is justified by direct action: the attempt to avert the harmful consequences, in contrast to the failure to take the necessary measures to prevent the harmful consequences of one's conduct contained in the third paragraph. By comparing the third and fourth paragraphs, we could conclude that the regulation in question implicitly distinguished between conduct, which in modern law we refer to as "commissive" and "omissive" conduct.

The fifth paragraph regulates the situation where a house fire occurred as a result of a natural event, and the fire spread to another person's house and damaged it. Even in this case, the JCP orders that the owner of a house whose house was lit by lightning and from whose house the fire spread further should not be condemned. The author of this part of the provision of art. 15 of the JCP implicitly relieves the owner of the house of any form of culpability and consequential liability (therefore no form of negligent culpability is allowed). This is a situation that we would call in our contemporary language force majeure. 
Based on the above, we can conclude that the legislation contained in art. 15 of the JCP distinguished between "intentional" and "negligent" arson, although the terms "intentional and unintentional culpability" were not known to the language of the time. The absence of these terms was replaced by a verbal description of these events as well as a determination of the consequence with a possible sanction. Likewise, the legislation of the time provided for different consequences in "negligent culpability", where the actor did not take the necessary measures to prevent damage and the situation where the actor took all measures to prevent damage.

Certainly interesting, and not accidental, is the order of the sentences governing the various forms of culpability: it starts with "intentional culpability", continues with "negligent culpability" with a higher degree of culpability, "negligent culpability" with a lower degree of culpability, and finally the situation, in which the person is released from liability for damage as a result of force majeure. This sequence (whether ascending or descending) is not accidental, but was most likely an intentional act of the drafter of this provision.

Although art. 15 of the JCP deals with forms of culpability only in a specific situation of damage to foreign property caused by ignition, we believe that the distinction between sanctioning or non-sanctioning other actions in the present language called "intentional" and "negligent" can be also assumed in other situations. Contemporary law probably used the "analogy of the kinship of action" much more than is permissible in modern law. As an example, we can cite the well-known norm contained in the Code of Hammurabi, which was also incorporated into the Old Testament and applied through it in many medieval legal systems spreading with Christianity. The wording "eye for eye, tooth for tooth" has certainly not only been applied to cases of eye peeling and tooth breakage, but also to a number of other situations in the event of any personal injury (or killing) or property damage. We assume that the description of the situation of distinguishing different forms of culpability in the "ignition of fire" could be applied in contemporary society to other situations where it was necessary to distinguish the consequences of the conduct based on the will aspect of the actor. The fact that such an analogy of solving a specific situation using a case similar to contemporary thinking was not entirely strange is also evidenced by a letter from Pope Nicholas I to the Bulgarians, ${ }^{32}$ in which response LV it is written that a statement should not be fulfilled according to the letter but according to the spirit. ${ }^{33}$

If the Great Moravian law contained in the Judicial Code for the People contained a distinction between "intentional and negligent culpability", we can state the relative maturity of this law. However, it is appropriate to ask whether such a distinction already existed before the arrival of Constantine and Methodius, or whether such a distinction was incorporated into domestic law by the Thessalonian brothers. On the basis that the institute of "intentional and negligent culpability" was in art. 15 of the JCP described only descriptively without the use of contemporary terms of the domestic language, we dare to state that probably Great Moravian law did not recognize the distinction between "intentional and negligent culpability" before 863. If it did, most likely the domestic language would already know the terms that could be used for it (as was the case with other institutes of contemporary law). In current legal-historical works ${ }^{34}$ on Cyril and Methodius $\operatorname{law}^{35}$, it has been pointed out several times that Constantine and Methodius, after their arrival in Great Moravia, used domestic language terms to denote legal institutes, on the basis of which

\footnotetext{
32 Answer LV does not respond directly to what is the subject of our present discussion, but we cite it as a recommendation to use the analogy of the similarity of situations.

33 Verum hoc sancti evangelii testimonum non per litteram, sed spisitum oportet impleri (MMFH IV, 65).

34 E. g. Gábriš - Jáger, 2016.

35 Patrik Petrás $(2017,251-261)$ commented on the issue of the correct use of the Slovak adjective cyrilometodský(Cyrillo-Methodian).
} 
it was stated that if contemporary language contained legal terms, most likely it also knew the institutes of law referred to by these terms. Thus, if Methodius, as the author of the Judicial Law for the People, used a purely description of the situation in a relatively extensive article 15 of the JCP, it is likely that the language of the time did not have term (s) to indicate various forms of culpability and therefore, probably domestic law did not even distinguish between different forms of culpability before 863 .

The author of the Judicial Code for the People was Methodius. ${ }^{36}$ As a trained lawyer, he knew the advanced Roman law used in the Byzantine Empire. Nevertheless, there are opinions that the author of the JCP allegedly did not understand some Roman law institutes during the translation and translated the passages of Roman law used in the Byzantine Empire incorrectly (e. g. Kizlink 1969, 476 interprets the punishment of self-help and its treatment as theft as a misunderstanding of the Roman law institute of self-help). We believe that the author of the JCP (Methodius) did not err in translating the original Roman law: we would like to support this statement by the absence of more serious translation errors in other translation works of Methodius. If the preserved parts of the JCP text were really an erroneous translation, these errors would be more likely to be caused by errors in the later rewriting of the original text. Such errors were very common in later transcripts. ${ }^{37}$ If the text of the norms of Great Moravian law differs from the Roman-law drafts, this may be due rather to the author's efforts to adapt to the specific social conditions of the domestic Great Moravian environment. Based on the above, we dare to state that the conceptual distinction between "intentional and unintentional culpability" is probably Methodius's "benefit" for Great Moravian law.

\section{REFERENCES}

Bartoňková, Dagmar et al. 1971. Magnae Moraviae Fontes Historici IV. Prameny k dějinám Velké Moravy. Praha - Brno.

Bartoňková, Dagmar et al. 2013. Magnae Moraviae Fontes Historici IV. Prameny k dějinám Velké Moravy. Praha - Brno.

Ďyačenko, Grigorij. 1993. Polnyi cerkovno-slavyansky slovar. Moskva.

Ferenčíková, Simona. 2018. Uloženie ochranného liečenia trestne nezodpovednému páchatelovi a náhrada škody. In Štát a právo 3, 22-40.

Gábriš, Tomáš - Jáger, Róbert. 2016. Najstaršie právo na Slovensku? Pokus o rekonštrukciu predcyrilometodského normatívneho systému. Bratislava.

Husár, Martin. 2016. Vybrané aspekty ceremónií a audiencií spojených s pobytom Konštantína a Metoda v Ríme. Otázky procesií a architektúry [Selected Aspects of Ceremonies and Audiences Connected With The Stay Of Constantine And Methodius In Rome. Process and Architecture Issues]. In Konštantínove listy [Constantine’s Letters] 9/1, 2938.

Ivanič, Peter. 2016. K problematike byzantských importov na území Velkej Moravy v 9. storočí [On The Issue Of Byzantine Imports In The Territory Of Great Moravia In The 9th Century]. In Konštantínove listy [Constantine’s Letters] 9/1, 3-10.

Ivanič, Peter. 2011. Západní Slovania v ranom stredoveku : história, kultúra, hospodárstvo, náboženstvo. Nitra.

Ivanič, Peter - Lukáčová, Martina. 2014a. Journeys of St. Methodius within the years 860 - 881 . In Istorija. Journal of History XLIX/1, 98103.

\footnotetext{
${ }_{36}$ His authorship has been questioned in the past (Kizlink,1969, 476).

37 See in more detail e. g. (MMFH IV, 169).
} 
Ivanič, Peter - Lukáčová, Martina. 2014b. Historickogeografický kontext misií solúnskych bratov (Cesty sv. KonštantínaCyrila a Metoda do roku 867). [Historical and Geographical Context of the Missions of the Thessalonian Brothers (The Journeys Of St. Constantine Cyril And Methodius To 867)]. In Konštantínove listy [Constantine's Letters] 7/1, 911.

Ivanič, Peter - Lukáčová, Martina. 2015. Svätý Metod na misijných a diplomatických cestách

(Historickogeografické súvislosti) (Saint Methodius on Missionary and Diplomatic Journeys (Historical Geographical Context)). In Historický časopis 63/4, 649659.

Jáger, Róbert. 2019a. Vina a zavinenie v stredovekom práve. Trnava.

Jáger, Róbert. 2019b. Poškodený v práve Velkej Moravy. In Banskobystrické zámocké dni práva.

Banská Bystrica.

Jáger, Róbert. 2017. Nomokánon - právnohistorická analýza a transcript. Banská Bystrica.

Kizlink, Karel. 1969. Právo Vel'kej Moravy (The Law of Great Moravia). In Právnické štúdie XVII/3, 165-172.

Kováč, Dušan et al. 1998. Kronika Slovenska I. Od najstarších čias do konca 19. storočia. Bratislava. Kurz, Josef. 1972. Slovník jazyka staroslověnského. diel 22. Praha.

Judák, Viliam. 1997. Vývin cirkevnej organizácie v 12. - 19. storočí na území Slovenska. In Mulík, Peter (ed.). Katolícka cirkev a Slováci. Zborník seminárov z odborného seminára 20 rokov samostatnej cirkevnej provincie. Bratislava, 21-30.

Lysý, Miroslav. 2014a. Moravania, Mojmírovci a Franská ríša. Štúdie k etnogenéze, politickým inštitúciám a ústavnému zriadeniu na území Slovenska vo včasnom stredoveku. Bratislava.

Lysý, Miroslav. 2014b. Kol'ko Gentes tvorilo základ politického zriadenia na Morave v 9.storočí? In Právo v priestore a čase. Zborník venovaný jubileu prof. JUDr. Jozefa Beňu, CSc. Bratislava, 120-135.

Mičková, Zuzana. 2018. Latinčina pre študentov práva. Banská Bystrica.

Petráš, Patrik. 2017. Problematika používania zloženého adjektíva cyrilo-metodský (cyrilometodovský): kodifikácia a jazyková prax. [The Topic of the Usage of the Complex Adjective 'cyrilo-metodský' ('cyrilo-metodovský'): Codification and Use in Language Practice]. In Konštantínove listy [Constantine’s Letters] 10/1, 251-261.

Saturník, Theodor. 1922. Příspěvky k šíření byzantského práva u Slovanů. Praha.

Stanislav, Ján. 1956. Dejiny slovenského jazyka. Bratislava.

Steinhübel, Ján. 2012. Kapitoly z najstarších českých dejín (531 - 1004). Krakov.

Vavřinek, Vladimír. 2013. Cyril a Metoděj - mezi Konstantinopolí a Rímem. Praha.

Zozulak, Ján. 2016. Byzantská filozofia. Plzeň.

Zozulak, Ján. 2016. Historické pozadie vzniku byzantskej filozofie [Historical Background of the Origin of Byzantine Philosophy]. In Konštantínove listy [Constantine's Letters] 9/1, 110-118.

Zozulaková, Viera. 2016. Praktická filozofia v živote Konštantína a Metoda [Practical Philosophy in the Life of Constantine and Methodius)]. In Konštantínove listy [Constantine's Letters] 9/1, 149-158.

Žeňuch, Peter (ed.). 2007. Cyrilské a latinské pamiatky v byzantsko-slovanskom obradovom prostredí na Slovensku. Bratislava.

Žigo, Pavol - Kučera, Matúš. 2012. Na písme zostalo. Bratislava. 
RÓBERT JÁGER

doc. JUDr. PhDr. Róbert Jáger, PhD.

Matej Bel University in Banská Bystrica

Faculty of Law

Department of History of State and Law

Komenského 20

97401 Banská Bystrica

Slovakia

robert.jager@umb.sk

ORCID ID: 0000-0001-6763-9245

WOS Researcher ID: AAT-8512-2021

SCOPUS Author ID: 57204071754 